Article

\title{
Growing Season Stem Water Status Assessment of Qinghai Spruce through the Sap Flow and Stem Radial Variations in the Qilian Mountains of China
}

\author{
Quanyan Tian ${ }^{1,4}$, Zhibin He ${ }^{1, *}$, Shengchun Xiao ${ }^{2}$, Jun Du ${ }^{1}$, Xiaomei Peng ${ }^{3}$, Longfei Chen ${ }^{1}$, \\ Pengfei Lin ${ }^{1,4}$, Xi Zhu ${ }^{1,4}$ and Aijun Ding ${ }^{1,4}$ \\ 1 Linze Inland River Basin Research Station, Chinese Ecosystem Research Network, Key Laboratory of \\ Eco-hydrology of Inland River Basin, Northwest Institute of Eco-Environment and Resources, \\ Chinese Academy of Sciences, Lanzhou 730000, China; tianquany@126.com (Q.T.); dujun159@126.com (J.D.); \\ chenlongfei_mail@163.com (L.C.); linpengfei@lzb.ac.cn (P.L.); zhuxi101@lzb.ac.cn (X.Z.); \\ dingaijun15@mails.ucas.ac.cn (A.D.) \\ 2 Key Laboratory of Eco-hydrology of Inland River Basin, Northwest Institute of Eco-Environment and \\ Resources, Chinese Academy of Sciences, Lanzhou 730000, China; xiaosc@lzb.ac.cn \\ 3 Key Laboratory of Desert and Desertification, Northwest Institute of Eco-Environment and Resources, \\ Chinese Academy of Sciences, Lanzhou 730000, China; pxmphd@163.com \\ 4 University of Chinese Academy of Sciences, Beijing 100049, China \\ * Correspondence: hzbmail@lzb.ac.cn; Tel.: +86-136-6930-4220
}

Received: 19 October 2017; Accepted: 11 December 2017; Published: 22 December 2017

\begin{abstract}
Global climate change is likely to change precipitation patterns with consequences for tree water use and growth in semi-arid areas. However, little is known about the effects of variability in precipitation on growth- and water-related physiological processes of native trees in dry areas of northwestern China. In this study, sap flow and stem radial variability in four Qinghai spruce trees (Picea crassifolia) were monitored in the Qilian Mountains, China. Tree water deficit $(\Delta W)$ and basal area increment (BAI) were calculated using stem radial variation; water-use efficiency (WUE) was then estimated as the ratio of BAI and sap flow (Jt). The results showed that sap flow density (Js) increased logarithmically with increasing $\Delta \mathrm{W}$ when $\Delta \mathrm{W}<50 \mu \mathrm{m}$, and then gradually stabilized. Multiple factor generalized additive models (GAM) showed that Js was closely related to all measured environmental variables except for daily mean temperature and relative air humidity. $\Delta \mathrm{W}$ was related to the minimum daily temperature and soil water content. WUE exhibited higher values in early July. Low WUE was observed under conditions of prolonged dry weather, but it quickly increased during rainy days. WUE decreased after precipitation events due to high transpiration. We concluded that, in these semi-arid areas, precipitation is the most important controlling factor in tree growth and transpiration.
\end{abstract}

Keywords: Qinghai spruce; stem radial changes; sap flow; environmental factors; water-use efficiency

\section{Introduction}

Climate change extensively affects natural mountain forests in semi-arid areas [1]. Changing precipitation patterns associated with climate change influences plant-available water and leads to changes in phenology, growth and water relations [2]. Climate change leads to increase in the frequencies of heat waves and drought events [3,4], which may affect growth and mortality rates of trees [5]. The Qilian Mountains, in the northeastern Tibetan Plateau, are the most important water source for the arid area of northwestern China, feeding the Shiyanghe, Shullehe, and the Heihe Rivers. Forests in these mountains play an important role not only in preventing desertification, but also in water conservation, which maintains the stability of oasis ecosystems in the middle and lower 
reaches of the inland river system [6]. However, the Qilian Mountains are sensitive to climate change. Several studies reported that temperature and heavy rainfall events increased, while the frequency of precipitation decreased in this area $[7,8]$. Previous research has focused mostly on the understanding of the response of stem radial changes and sap flow to environmental factors [9-11], and on the relationship between sap flow and stem growth $[12,13]$. However, the effects of climate-induced environmental changes on the growth- and water-related physiological processes, in particular, on sap flow and stem radial changes, have not been sufficiently studied in the Qilian Mountains.

Tree stem radial changes can be continuously monitored at high temporal resolution using dendrometers, which include information on stem radial growth and fluctuations in tree water use [13-16]. Several authors reported that relative air humidity, air temperature, vapor pressure deficit, and soil matric potential had significant influence on tree water deficit and stem radial growth [17-22]. Zweifel [23] proposed a method, assuming that stems exhibited zero growth during periods of shrinking, to extract growth trends with irreversible expansion and estimate tree water deficit $(\Delta W)$ as a physiological measure of drought stress. Tree water deficit can be used to analyze tree water relation patterns and their dependency on environmental drivers at high temporal resolutions [24].

Sap flow, measured by the heat-ratio method [25-27], can be used to study water-related physiological processes in trees. Most research focused on estimating whole-tree water use or transpiration [28-30], and on environmental controls on sap flow [31,32], while the link between sap flow and stem radial changes has been relatively less studied [3,12,13,33,34].

Integrated water-use efficiency (WUE), the ratio between productivity and water use, can be expressed as the ratio of basal area increment (BAI) and sap flow [12,35], which are the eco-physiological indices assessing the growth adaptability of trees. A previous study showed that WUE can be used as an indicator of drought tolerance, and that drought-tolerant shallow-rooted species typically had a higher WUE than deep-rooted ones [36]. With the changes of climate and precipitation patterns, it is necessary to understand the water use strategies of trees.

Qinghai spruce (Picea crassifolia) is commonly found in the Qilian Mountains, and constitutes one of the most important long-lived evergreen tree species in the area. Qinghai spruce grows on shaded or semi-shaded slopes at elevations ranging from 2600 to $3400 \mathrm{~m}$ [37]. Previous studies of Qinghai spruce in this area focused on radial patterns of sap velocity, stand transpiration, and canopy conductance [6,29], the response of stem radial growth to environmental factors [38], and interannual intrinsic water-use efficiency based on tree-ring stable isotope of carbon $\left(\delta^{13} \mathrm{C}\right)$ [39]. However, little is known about the efficacy of assessment of water stress in Qinghai spruce, and about the response of water stress to environmental factors. Moreover, the relationship between sap flow and water stress, and water use strategy in different growth periods of Qinghai spruce remain unclear.

In this study, we monitored seasonal sap flow and stem radial changes of four Qinghai spruce trees during the growing season of 2016; environmental factors were monitored synchronously. The main objectives were to (1) explore the relationship between Js and $\Delta W$ of Qinghai spruce, (2) test the response of Js and $\Delta W$ to environmental factors during the monitored periods, and (3) assess WUE in different growth periods using sap flow and stem radial growth.

\section{Materials and Methods}

\subsection{Study Area}

This study was conducted at the upper limit of Qinghai spruce natural forest (3200 m elevation) on a north-facing slope in the Pailugou watershed in the central Qilian Mountains ( $100^{\circ} 17^{\prime} 28.2^{\prime \prime}$ E, $\left.38^{\circ} 32^{\prime} 40.1^{\prime \prime} \mathrm{N}\right)$. The study area has a continental climate with cold and dry winters, and warm and wet summers. Apart from occasional scattered bare rocks, the main soil type is gray-cinnamon soil with an average soil depth of $50 \mathrm{~cm}$. Soil surface is covered with about a 5-cm thick layer of moss. Data collected since 2001 at the weather station located in the watershed at $2700 \mathrm{~m}$ elevation $\left(100^{\circ} 17^{\prime} 05^{\prime \prime} \mathrm{E}, 38^{\circ} 33^{\prime} 19^{\prime \prime}\right.$ $\mathrm{N}$ ) indicated that the mean annual air temperature was $0.5^{\circ} \mathrm{C}$, and the mean maximum and minimum 
annual air temperatures were 28.0 and $-36.0^{\circ} \mathrm{C}$, respectively. The mean annual precipitation at an elevation of $2700 \mathrm{~m}$ was $375.5 \mathrm{~mm}$, of which $70 \%$ fell from May to September.

Qinghai spruce is the dominant tree species at the study site. Above the treeline, trees are replaced by low shrubs, such as Potentilla fruticosa and Rhododendron przewalskii. Qinghai spruce ranges in age from 80 to 140 years old, and stand density is approximately 1100 trees/ha. For our study, four adult Qinghai spruce trees were selected based on tree diameter at breast height (DBH) and heights to measure the changes in sap flow and stem radial change (Table 1).

Table 1. Parameters of the four measured trees.

\begin{tabular}{cccccccc}
\hline Tree & $\begin{array}{c}\text { Height } \\
\mathbf{( m )}\end{array}$ & $\begin{array}{c}\text { Diameter at } \\
\text { Breast Height } \\
(\mathbf{c m})\end{array}$ & $\begin{array}{c}\text { Tree Age } \\
\text { (years) }\end{array}$ & $\begin{array}{c}\text { Bark Depth } \\
\mathbf{( c m )}\end{array}$ & $\begin{array}{c}\text { Sapwood } \\
\text { Depth } \mathbf{( c m )}\end{array}$ & $\begin{array}{c}\text { Sapwood } \\
\text { Area-Out } \\
\left(\mathbf{c m}^{2}\right)\end{array}$ & $\begin{array}{c}\text { Sapwood } \\
\text { Area-In } \\
\left(\mathbf{c m}^{\mathbf{2}} \mathbf{)}\right.\end{array}$ \\
\hline Tree1 & 11 & 18.6 & 95 & 0.6 & 3.43 & 74.93 & 75.55 \\
Tree2 & 13 & 25 & 104 & 0.6 & 4.02 & 105.09 & 144.87 \\
Tree3 & 19 & 44 & 133 & 0.6 & 6.47 & 194.62 & 543.75 \\
Tree4 & 17 & 33 & 117 & 0.6 & 4.91 & 142.79 & 272.26 \\
\hline
\end{tabular}

\subsection{Sap Flow Measurements and Related Parameters}

Sap flow was monitored using the heat ratio method (HRM) with sensors (HRM-30, ICT International Pty Ltd., Armidale, NSW, Australia) measuring simultaneously in the four experimental trees, and continuously during the growing season of 2016 (from May to September, day of year 122-274). Sensors, $35 \mathrm{~mm}$ long with two thermocouples at 7.5 and $22.5 \mathrm{~mm}$ from the tip, representing sapwood area of inside and outside respectively (Table 1), were connected to a data logger (Smart logger, ICT, Armidale, NSW, Australia). The probes were inserted into the tree xylem tissue at breast height $(1.3 \mathrm{~m})$ at the north side after the outer bark had been removed.

Heat pulses were emitted every $30 \mathrm{~min}$. Heat pulse velocity was calculated after Marshall and Burgess et al. [40,41]. Heat pulse velocity was corrected for wound effects, and then sap velocity (Vs) was calculated from the corrected heat pulse velocity [41,42]. Sapwood area and sapwood depth of monitored trees were estimated using the relationship between sapwood area and DBH for Qinghai spruce [29] (Table 1). Sap flow density $\left(\mathrm{Js}, \mathrm{kg} \cdot \mathrm{m}^{-2} \cdot \mathrm{h}^{-1}\right.$ ) and sap flow $\left(\mathrm{Jt}, \mathrm{kg} \cdot \mathrm{d}^{-1}\right.$ ) were calculated based on sap velocity and sapwood area of inside and outside for each monitored tree Daily-weighted average Js and Jt of monitored trees were then calculated based on DBH to represent the average values for the study site.

\subsection{Stem Radial Change Measurements and Related Parameters}

High-resolution automatic point dendrometers (EcoMatik, Germany; type radius dendrometer (DR), accuracy $\pm 2 \mu \mathrm{m}$, temperature coefficient $<0.1 \mu \mathrm{m} / \mathrm{K}$ ) were employed to measure stem radial changes. We installed a dendrometer at a height of $1.2 \mathrm{~m}$ on each of the four trees under the sap flow sensors. To reduce the effects of bark expansion and shrinkage on the accuracy of measurement, outer bark was removed without wounding of the cambial zone. Stem radial changes were recorded every 30 min using a data logger (EcoMatik, Germany). Dendrometer data of stem radial changes include water content variability and growth; therefore, stem radial changes of each tree were detrended for growth based on the zero-growth concept as described in Zweifel [23] (Figure 1a,b), and used to indicate drought stress in trees [21,43]. Tree water deficit $(\Delta W)$ was calculated as the difference between the past highest stem radial record (SRmax) and current stem radial reading (SRt) when $\mathrm{SRt}<\mathrm{SRmax}$, with $\Delta \mathrm{W}=0$ when SRt $>$ SRmax [24], that is, the difference between growth trend and stem radial fluctuations (Figure 1a,b and Figure 2d). A $\Delta \mathrm{W}$ of zero indicated an optimal water content of the cambial zone, while increasingly positive values meant increasing water stress. For the purpose of this analysis, the 30-min $\Delta \mathrm{W}$ data for each tree were transformed into daily-averaged values (Figure 2e). Then, the weighted mean $\Delta \mathrm{W}$ was calculated using daily-averaged values for each tree based on $\mathrm{DBH}$. 


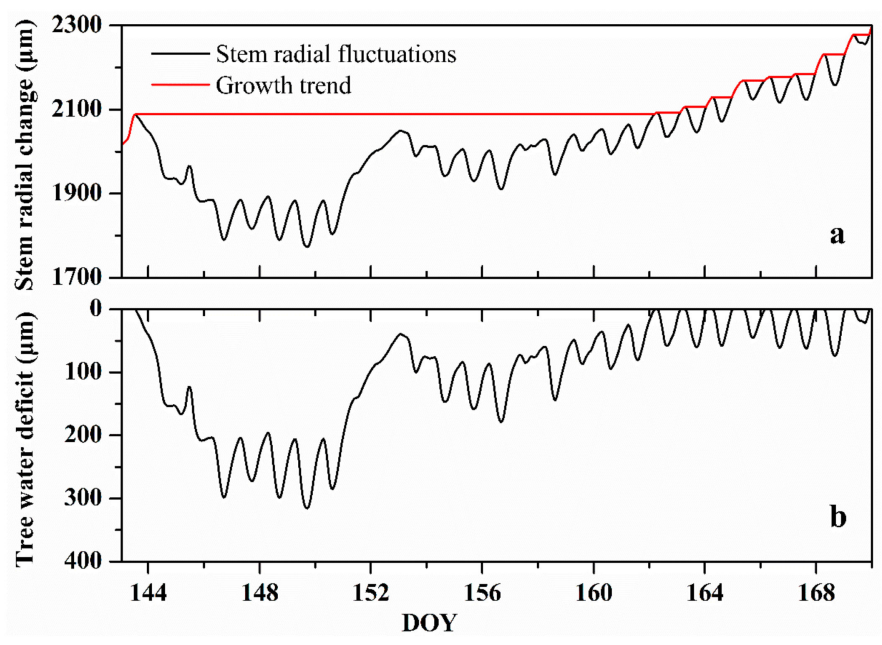

Figure 1. Example of tree water deficit calculation, showing the stem radial fluctuations (black line) and the growth trend according to the zero growth concept (red line) (a), tree water deficit, as the difference between the growth trend and stem radial fluctuations $(\mathbf{b})$. Examples of data recorded in one tree between day of year (DOY) 144 to 170.
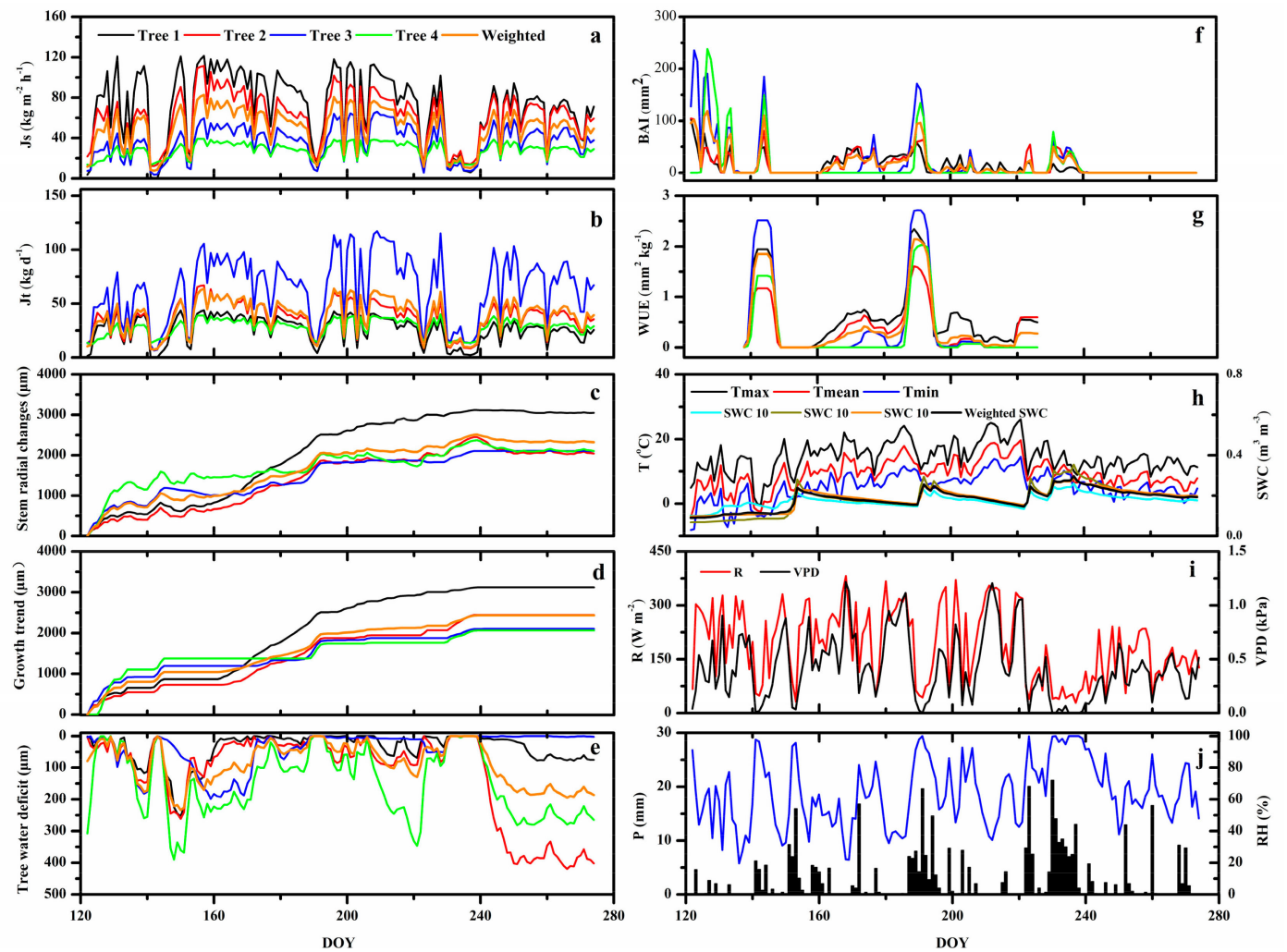

Figure 2. Time series of sap flow density (Js) (a), sap flow (Jt) (b), stem radial changes (c), growth trends (d), tree water deficit (e), basal area increment (BAI) (f) and water use efficiency (WUE) (g) in four sample trees from the day of year (DOY) 122 to 274 of 2016; air temperature (T) and soil water content (SWC) (h), daily mean solar radiation (R) and vapor pressure deficit (VPD) (i), precipitation (P) and relative air humidity $(\mathrm{RH})(\mathbf{j})$.

Based on the growth trend, daily weighted mean basal area increment $\left(\mathrm{BAI}, \mathrm{cm}^{2}\right)$ of monitored trees was calculated (Figure 2f). To study water use strategies of Qinghai spruce for different growth 
periods, water-use efficiency (WUE) was defined as the ratio of BAI and Jt (WUE = BAI/Jt) [12]. Daily WUE was calculated based on the weighted mean BAI and Jt. To alleviate fluctuations of daily WUE, a moving average for a 7-day period was used (Figure 2g).

\subsection{Environmental Records}

To study the response of sap flow and tree water deficit to environmental variables, an automated weather station was installed in an open and relatively flat space above the treeline, within $50 \mathrm{~m}$ of the monitored trees. Air temperature $\left(\mathrm{T},{ }^{\circ} \mathrm{C}\right)$, relative air humidity $(\mathrm{RH}, \%)$, solar radiation $\left(\mathrm{R}, \mathrm{W} \cdot \mathrm{m}^{-2}\right)$, and precipitation $(\mathrm{P}, \mathrm{mm})$ were measured continuously. Vapor pressure deficit $(\mathrm{VPD}, \mathrm{kPa})$ was calculated from the values of $\mathrm{T}$ and $\mathrm{RH}$.

To continuously measure soil water content $\left(\mathrm{SWC}, \mathrm{cm}^{3} \cdot \mathrm{cm}^{-3}\right.$ ), $5 \mathrm{TM}$ sensors (Decagon Devices Inc., Pullman, WA, USA) were installed close to the monitored trees. An Em50 was employed to collect data. Soil water content was measured at depths of 10, 20,40, and $60 \mathrm{~cm}$. Because up to $95 \%$ of roots of Qinghai spruce are found up to $45 \mathrm{~cm}$ of soil depth, weighted mean soil water contents were calculated for analyses according to soil depth and water content at 10,20, and $40 \mathrm{~cm}$ soil layers. Environmental variables were recorded every 30 min synchronously with the sap flow and dendrometer measurements.

\subsection{Data Analysis}

Nonlinear models were used to analyze the relationships between daily weighted mean Js and $\Delta \mathrm{W}$ in OriginPro 8.5 (OriginLab Inc., Northampton, MA, USA).

The generalized additive models (GAM, mgcv package in R) provide a flexible method to predict the quality of dependent variables from different distributions with different regression models [44]. In our study, two GAMs were used to investigate the associations between Js and $\Delta \mathrm{W}$, and environmental variables. Model 1 was a single-factor GAM model that explored the association between each of the environmental factors (R, Tmax, Tmean, Tmin, RH, P, VPD, and SWC) and Js and $\Delta \mathrm{W}$, with the following equation:

$$
g(\mu)=\alpha+s(X)
$$

where $g$ was the link function, $\mu$ was the expectation of observations, $\alpha$ was the intercept, $X$ was the explanatory variable (environmental factors), and $s$ was a smooth function. Model 2 was a multiple-factor GAM model that explored the integrated effects of environmental factors on Js and $\Delta \mathrm{W}$, with the following equation:

$$
g(\mu)=\alpha+\sum_{i=1}^{n} s_{i}\left(X_{i}\right)
$$

where $X_{i}$ was the ith explanatory variable, $s_{i}$ was a smooth function, and the meaning of other parameters was the same as in Equation (1). In our study, both of the models', due to the normal distribution of Js and $\Delta \mathrm{W}$ data, identity link functions are chosen as link functions, which involve no transformation of variables; the thin plate regression spline is used for each smooth function.

\section{Results}

\subsection{Environmental Variables}

During the monitoring period (from May to September) of 2016, the average air temperature was $9.3{ }^{\circ} \mathrm{C}$. Minimum and maximum air temperatures were, respectively, $-8.1^{\circ} \mathrm{C}$ recorded in May, and $26.1^{\circ} \mathrm{C}$ recorded in August (Figure 2h). Water content at 10, 20 and $40 \mathrm{~cm}$ soil depth ranged from 0.07 to $0.35 \mathrm{~cm}^{3} \cdot \mathrm{cm}^{-3}$, and the weighted mean soil water content was $0.18 \mathrm{~cm}^{3} \cdot \mathrm{cm}^{-3}$. Precipitation events resulted in fluctuation of soil water content, which subsided with a continuous heavy rainfall (Figure $2 \mathrm{~h}, \mathrm{j}$ ). Daily mean solar radiation and vapor pressure deficit ranged from 28.30 to $381.88 \mathrm{~W} \cdot \mathrm{m}^{-2}$, and from 0 to $1.22 \mathrm{kPa}$, respectively (Figure 2i). Relative air humidity ranged from 19.7 to $100 \%$ 
(Figure 2j). Total amount of precipitation for the monitoring period was $424.0 \mathrm{~mm}$, of which about $75 \%$ was recorded from June to August (Figure 2j). Compared with the mean annual precipitation, 2016 was a wet year.

Most of the environmental variables were influenced by rainfall. On rainy days, air temperature, solar radiation, and vapor pressure deficit decreased, while relative air humidity increased (Figure 2).

\subsection{WUE and the Relationship between Sap Flow Density and Tree Water Deficit}

From May to September, sap flow density in experimental trees ranged from 3.68 to $121.37 \mathrm{~kg} \mathrm{~m}^{-2} \cdot \mathrm{h}^{-1}$, and weighted mean sap flow density ranged from 7.72 to $82.84 \mathrm{~kg} \cdot \mathrm{m}^{-2} \cdot \mathrm{h}^{-1}$. Sap flow density fluctuated with changes in environmental variables, and exhibited low values on rainy days (Figure 2a). Tree water deficit ranged from 0 to $419 \mu \mathrm{m}$. Weighted mean tree water deficit ranged from 0 to $234 \mu \mathrm{m}$. Values of $\Delta \mathrm{W}$ were higher in late May, early June, August, and in September than at other times (Figure 2e). The nonlinear model showed that Js increased logarithmically with an increase in $\Delta \mathrm{W}$, and the nonlinear regression explained $63 \%$ of the variation (Figure 3). These results showed that Js increased quickly with the increase in $\Delta \mathrm{W}$ when $\Delta \mathrm{W}<50 \mu \mathrm{m}$, and gradually stabilized when $\Delta \mathrm{W}>50 \mu \mathrm{m}$.

The weighted mean sap flow ranged from 7.19 to $63.87 \mathrm{~kg} \cdot \mathrm{d}^{-1}$, while BAI ranged from 0 to $118.7 \mathrm{~mm}^{2}$ (Figure $2 \mathrm{~b}, \mathrm{f}$ ). Sap flow was high in June and most of July. BAI was at a maximum in early May, and exhibited another peak in early July. In September, BAI was equal to 0. From mid-May to early August, WUE ranged from 0 to $2.72 \mathrm{~mm}^{2} \cdot \mathrm{kg}^{-1}$ and weighted mean WUE ranged from 0 to $2.21 \mathrm{~mm}^{2} \cdot \mathrm{kg}^{-1}$, exhibiting the same trend as BAI (Figure $2 \mathrm{~g}$ ). Values of WUE were higher in late May and early July than in other periods.

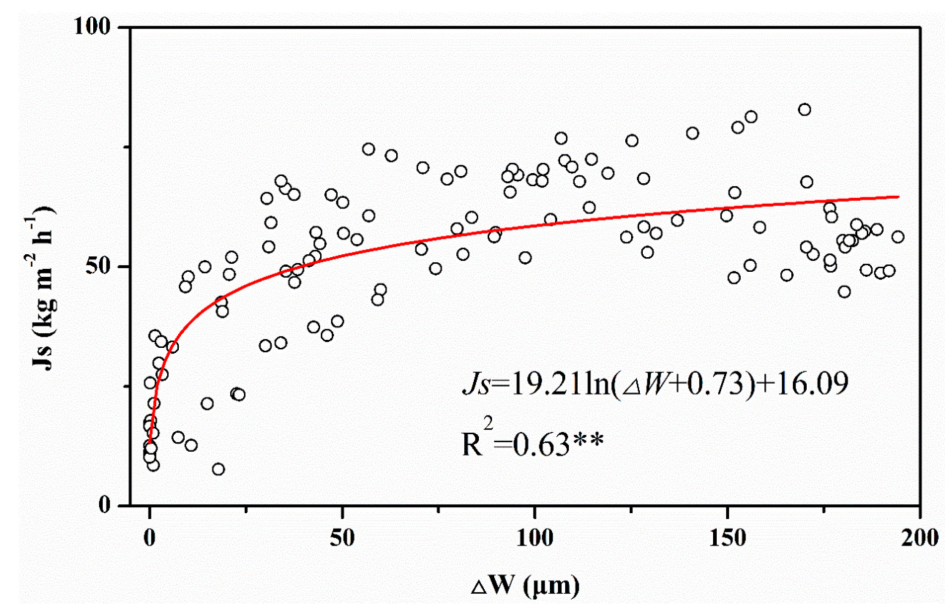

Figure 3. The relationship between sap flow density (Js) and tree water deficit $(\Delta \mathrm{W})$ for Qinghai spruce from May to August of 2016 after removed several outliers in the constant heavy rainy days and 2-5 days after heavy rain. ${ }^{* *} p<0.01$.

\subsection{Response of Sap Flow Density and Tree Water Deficit to Environmental Variables}

The relationships between Js, $\Delta \mathrm{W}$, and environmental variables indicated that Js was nonlinearly related to R, Tmax, Tmin RH, P, VPD, and SWC, and nearly positively linearly related to Tmean. Js dramatically increased at first, and then remained steady when $\mathrm{R}>150 \mathrm{~W} \cdot \mathrm{m}^{-2}$ and VPD $>0.6 \mathrm{kPa}$, but sharply decreased when $\mathrm{RH}>60 \%$ (Figure 4 ). All environmental variables were significantly correlated with Js $(p<0.01)$ and the adjusted $R^{2}$ ranged from 0.139 to 0.812 (Table 2). Results of GAMs showed that $\triangle W$ was significantly nonlinearly related to R, Tmin, VPD and SWC, and significantly negatively related to $\mathrm{RH}$ and $\mathrm{P}$ (Figure 5). The adjusted $R^{2}$ ranged from 0.013 to 0.374 (Table 2). Based on adjusted $R^{2}$, SWC significantly influenced $\Delta \mathrm{W}$, while Tmax and P had less of an effect than other environmental factors. 

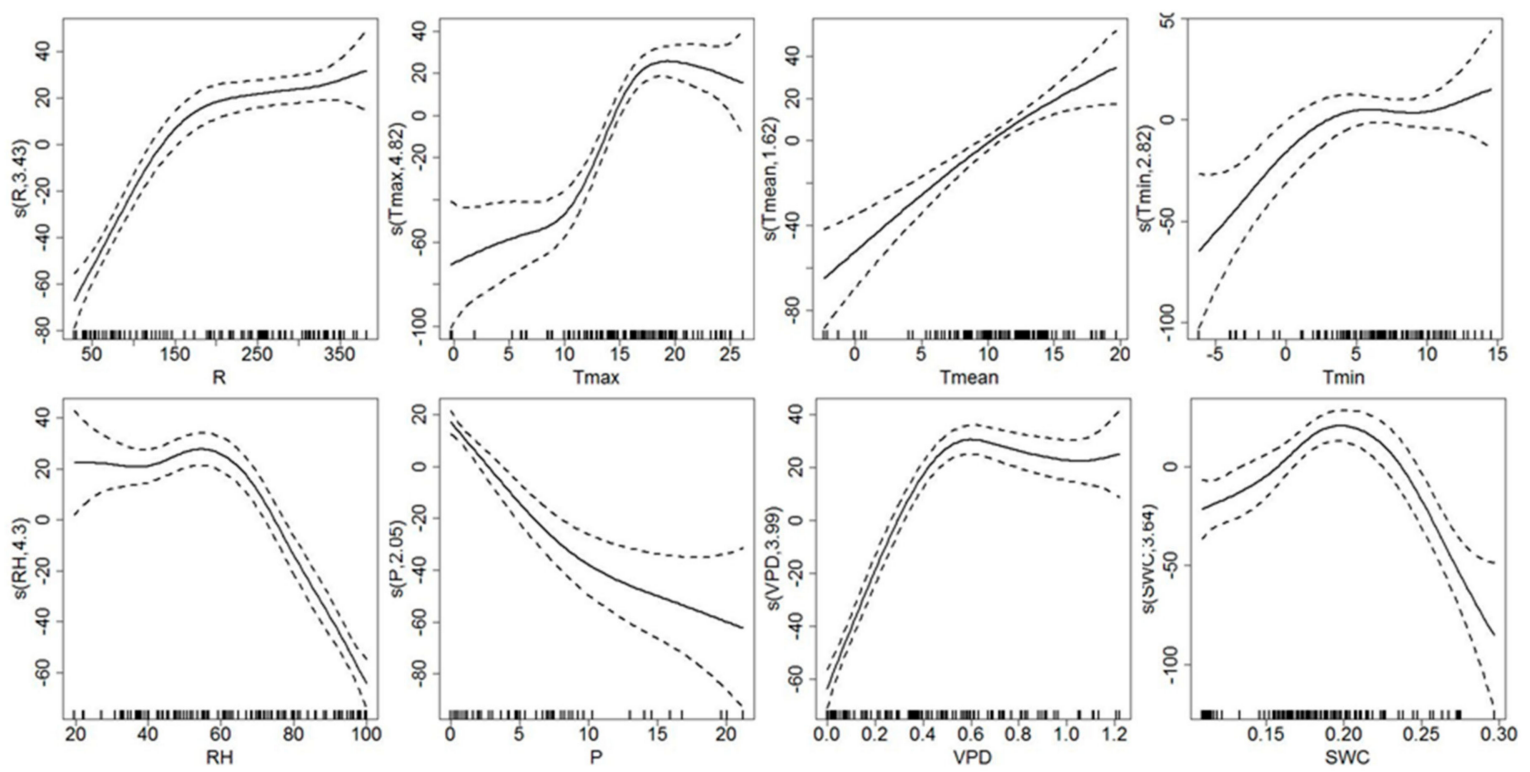

Figure 4. Effects of environmental variables on sap flow density. Each graph is a generalized additive model (GAM) output. Tick marks on the $x$-axis are observed data points. The $y$-axis represents the spline function, and the numbers are degree of freedom. Dashed lines indicate $95 \%$ confidence intervals.
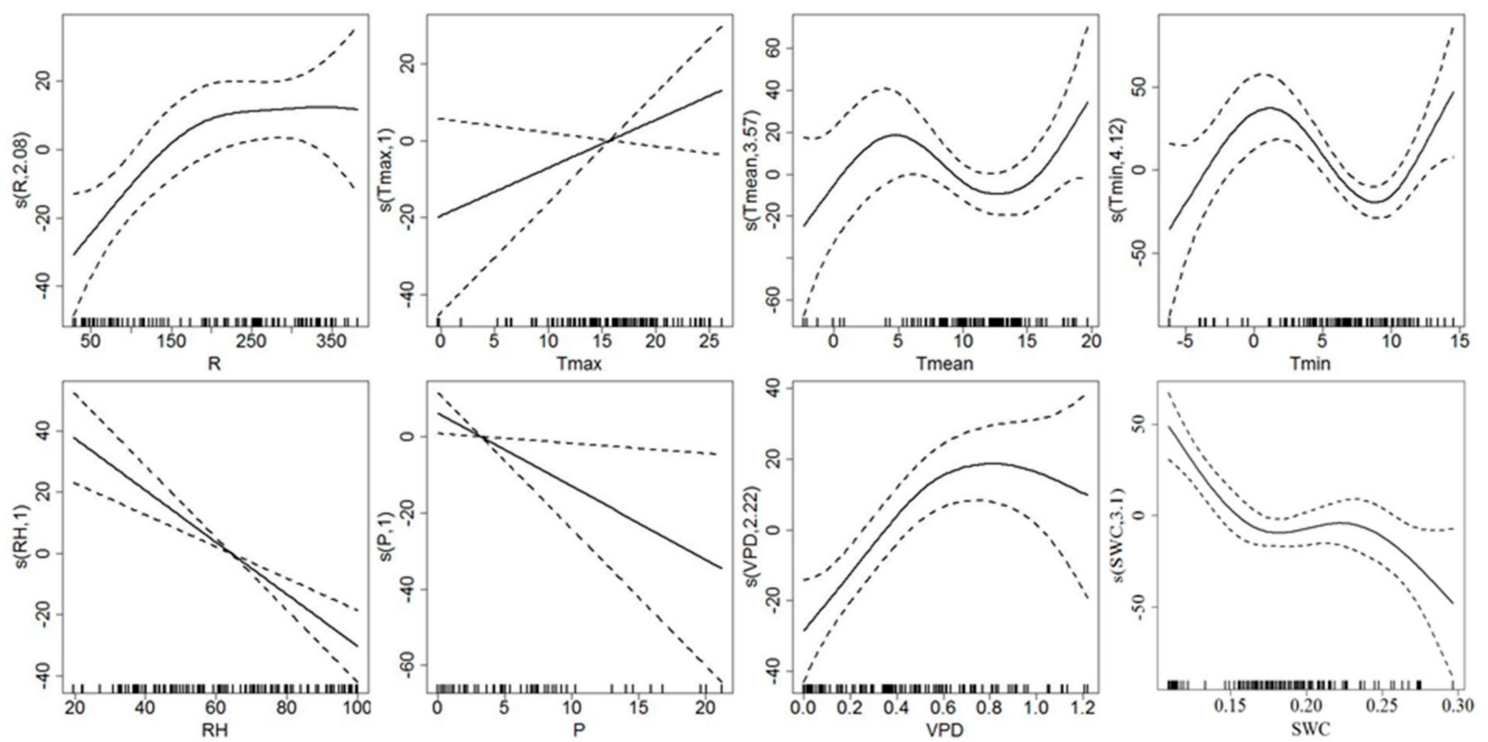

Figure 5. Effects of environmental variables on tree water deficit. Each graph is a modelled GAM output. Tick marks on the $x$-axis are observed data points. The $y$-axis represents the spline function, and the numbers are degree of freedom. Dashed lines indicate $95 \%$ confidence intervals.

When we selected all the environmental variables for model 2 to explore the integrated effects of environmental factors on Js and $\Delta \mathrm{W}$, the results indicated that Js was significantly nonlinear related to all the environmental factors except for Tmean and $\mathrm{RH}$, while $\Delta \mathrm{W}$ was only significantly nonlinear related to Tmin and SWC (Table 3). The adjusted $R^{2}$ were 0.956 and 0.781 , respectively. When reselected the environmental factors significantly associating with Js or $\Delta W$ for model 2, the shapes of the functional forms for the environmental factors with Js and $\Delta \mathrm{W}$ are similar to the result of model 1 . The adjust $R^{2}$ were 0.956 and 0.668 , respectively (Table 4). 
Table 2. GAM results of tests for the relationships between Js and $\triangle W$, and single environmental variables.

\begin{tabular}{cccccccccc}
\hline \multirow{2}{*}{ Observation } & $\begin{array}{l}\text { Statistics } \\
\text { Variable }\end{array}$ & $\mathbf{R}$ & Tmax & Tmean & Tmin & $\mathbf{R H}$ & $\mathbf{P}$ & VPD & SWC \\
\hline \multirow{2}{*}{ Js } & edf & 3.43 & 4.825 & 1.623 & 2.819 & 4.3 & 2.051 & 3.992 & 3.635 \\
& $\mathrm{~F}$ & 60.3 & 26.74 & 22.01 & 4.916 & 56.13 & 26.14 & 91.3 & 13.38 \\
& $p$-value & $0.000^{* *}$ & $0.000^{* *}$ & $0.000^{* *}$ & $0.000^{* *}$ & $0.000^{* *}$ & $0.000 * *$ & $0.000^{* *}$ & $0.000^{* *}$ \\
& $R^{2}$-adj & 0.71 & 0.598 & 0.293 & 0.139 & 0.738 & 0.382 & 0.812 & 0.364 \\
& Dev & $72 \%$ & $61.70 \%$ & $30.40 \%$ & $16.20 \%$ & $74.90 \%$ & $39.40 \%$ & $81.90 \%$ & $38.60 \%$ \\
\hline \multirow{2}{*}{$\mathrm{W}$} & edf & 2.08 & 1 & 3.567 & 4.121 & 1 & 1 & 2.224 & 3.097 \\
& F & 5.64 & 2.422 & 2.049 & 5.841 & 26.57 & 5.363 & 7.176 & 9.686 \\
& $p$-value & $0.002^{* * *}$ & 0.123 & 0.0824 & $0.000 * *$ & $0.000 * *$ & $0.022^{*}$ & $0.000 * *$ & $0.000 *$ \\
& $R^{2}$-adj & 0.12 & 0.013 & 0.074 & 0.229 & 0.196 & 0.039 & 0.16 & 0.237 \\
& Dev & $13.80 \%$ & $2.28 \%$ & $10.60 \%$ & $25.90 \%$ & $20.40 \%$ & $4.90 \%$ & $17.80 \%$ & $26.00 \%$ \\
\hline
\end{tabular}

Js: sap flow density; $\triangle W$ : tree water deficit; R: daily mean solar radiation; Tmax: maximum air temperature; Tmean: mean air temperature; Tmin: minimum air temperature; RH: relative air humidity; P: precipitation; VPD: vapor pressure deficit; SWC: soil water content; edf: estimated degrees of freedom; Dev: deviation explained. ${ }^{*} p<0.05$, ** $p<0.01$.

Table 3. GAM results of tests for the relationships between Js and $\triangle W$, and combined environmental variables.

\begin{tabular}{ccccccc}
\hline Observation & Environmental Variables & edf & F & $p$-Value & $\boldsymbol{R}^{2}$-adj & Dev \\
\hline Js & R & 3.409 & 4.641 & $0.001^{* *}$ & & \\
Tmax & 4.364 & 2.848 & $0.017^{*}$ & & \\
Tmean & 1 & 1.592 & 0.211 & & \\
Tmin & 3.897 & 3.842 & $0.004^{* *}$ & 0.956 & $96.90 \%$ \\
RH & 1 & 0.849 & 0.359 & & \\
P & 4.484 & 3.426 & $0.006^{* *}$ & & \\
VPD & 3.455 & 6.782 & $0.000^{* *}$ & & \\
& SWC & 8.59 & 9.134 & $0.000^{* *}$ & & \\
& R & 1 & 0.479 & 0.491 & & \\
Tmax & 3.55 & 0.96 & 0.434 & & \\
Tmean & 1 & 0.276 & 0.601 & & \\
Tmin & 4.835 & 8.093 & $0.000^{* *}$ & 0.781 & \\
RH & 3.386 & 1.672 & 0.159 & & \\
P & 1 & 0.344 & 0.559 & & \\
& VPD & 6.366 & 0.947 & 0.345 & & \\
& SWC & 8.213 & 14.117 & $0.000 * *$ & & \\
& & & &
\end{tabular}

edf: estimated degrees of freedom; Dev: deviation explained. ${ }^{*} p<0.05,{ }^{* *} p<0.01$.

Table 4. GAM model results for the relationships between Js and $\triangle W$, and combined environmental factors.

\begin{tabular}{ccccccc}
\hline Observation & Environmental Variables & edf & F & $p$-Value & $\boldsymbol{R}^{2}$-adj & Dev \\
\hline \multirow{2}{*}{ Js } & R & 3.637 & 4.152 & $0.003^{* *}$ & & \\
& Tmax & 4.536 & 2.702 & $0.024^{*}$ & & \\
Tmin & 3.907 & 3.745 & $0.004^{* *}$ & 0.956 & $96.80 \%$ \\
P & 4.525 & 3.157 & $0.011^{*}$ & & \\
& VPD & 3.805 & 10.569 & $0.000^{* *}$ & & \\
& SWC & 8.503 & 10.274 & $0.000^{* *}$ & & \\
\hline \multirow{2}{*}{$\triangle W$} & Tmin & 5.354 & 14.29 & $0.000^{* *}$ & \multirow{2}{*}{0.668} & $71.20 \%$ \\
& SWC & 8.432 & 15.58 & $0.000^{* *}$ & & \\
\hline
\end{tabular}

edf: estimated degrees of freedom; Dev: deviation explained. ${ }^{*} p<0.05,{ }^{* *} p<0.01$. 


\section{Discussion}

\subsection{Seasonal Course of Sap Flow Density and Tree Water Deficit}

A previous study reported that Js for different species had a nonlinear negative relationship to $\Delta \mathrm{W}$ when VPD $>0.5 \mathrm{kPa}$ and solar radiation $>150 \mathrm{~W} \cdot \mathrm{m}^{-2}$, and that it was related to soil water content [12]. However, we observed a strong nonlinear increase in Js with an increase in $\Delta \mathrm{W}$ in Qinghai spruce, with Js subsequently gradually stabilizing when $\Delta \mathrm{W}$ reached over $50 \mathrm{~mm}$ (Figure 3). Tree water deficit increased when water loss by transpiration was higher than recharge by root uptake. To meet the needs of transpiration, an increased sap flow velocity was needed. However, due to environmental limitations on sap flow (Figure 3), Js maintained a certain level even though $\Delta \mathrm{W}$ increased further. In fact, Js declined somewhat when $\Delta \mathrm{W}>170 \mu \mathrm{m}$, probably due to low soil water content. Root water uptake was limited, resulting in the closure of leaf stomata [45]. The effects of these conditions may lead to the use of tree storage water for transpiration [34,46], and a further increase in $\Delta \mathrm{W}$.

\subsection{Environmental Control on Sap Flow Density and Tree Water Deficit}

Change in sap flow is a mechanism by which a tree meets its demand for transpiration [47], and sap flow density is directly related to tree water consumption by transpiration. Tree water deficit is an indicator of tree water status. Both of these variables are complex physiological responses to environmental variability. Previous studies reported that sap flow exhibited significant positive correlations with solar radiation, air temperature and vapor pressure deficit [6,11,48-51]. In our study, the results of single factor GAM models showed that Js increased in a nonlinear mode with increasing R and VPD during May to September (Figure 4). However, Js tended to plateau when R and VPD exceeded a certain value (Figure 4) due to the overriding effect of these factors on stomatal or crown conductance [50,52,53]. A decline in crown conductance [54] and stomatal closure [55] with increasing solar radiation and vapor pressure deficit limited tree water fluxes. Js was also nonlinearly negatively related to $\mathrm{RH}$ and precipitation, especially when $\mathrm{RH}>60 \%$ (Figure 4). The transpiration rate decreased with increasing $\mathrm{RH}$ and precipitation, resulting in a lower Js. Js was also negatively related to SWC when SWC $<0.25 \mathrm{~m}^{3} \cdot \mathrm{m}^{-3}$. High soil water content is beneficial for root water uptake, increasing sap flow. A number of research papers reported that sap flow was positively correlated with air temperature [6,56,57], and this was consistent with our results. Generally, high air temperature increased transpiration and promoted sap flow.

Tree water deficit represented drought stress in trees, which is a comprehensive response to environmental factors (Figure 5). The significant positive nonlinear relationships between $\Delta \mathrm{W}$ and $\mathrm{R}$, and $\triangle \mathrm{W}$ and VPD suggested that drought stress intensified with high solar radiation and vapor pressure deficit. High values of both factors increased water loss by transpiration, exacerbating drought stress $[12,58,59]$. Several studies reported that $\Delta W$ was significantly positively related to air temperature $[18,19]$, which both influence transpiration. In our study, however, $\Delta \mathrm{W}$ was not significantly correlated with Tmax or Tmean, but was significantly nonlinearly correlated with Tmin (Figure 5); most of the values of Tmin were in the range of $0-10{ }^{\circ} \mathrm{C}$, and $\Delta \mathrm{W}$ was negatively related to Tmin. Water supply through root uptake at nighttime benefitted from high daily minimum air temperature [60], which reduced tree water stress. $\Delta \mathrm{W}$ increased with decreasing $\mathrm{P}$ and $\mathrm{RH}$. On one hand, precipitation recharged soil water, and more moisture was available, directly alleviating water shortage of trees. On the other hand, due to lower R and VPD and higher RH on overcast or rainy days, transpiration rate was lower, resulting in a decrease in tree water stress [61,62]. Previous studies showed that $\Delta W$ decreased with improved soil moisture conditions $[3,18,19,43] . \Delta W$ in Qinghai spruce in our study was significantly nonlinearly related to $\mathrm{SWC}$, and $\Delta \mathrm{W}$ showed an overall decreasing trend with increased SWC. This facilitated moisture absorption by roots when soil water was available, decreasing tree water stress.

The results of multiple factor GAM models showed that Js and $\Delta \mathrm{W}$ were affected by the combination of environmental factors. Js was not significantly related to Tmean and $\mathrm{RH}$, which may 
be because the values of VPD were calculated using these two factors. $\triangle \mathrm{W}$ was affected by Tmin and SWC, indicating that these two factors influenced root water uptake.

\subsection{Effects of Environmental Variables on Water Use Efficiency}

In our study, WUE reflected a combination of sap flow and stem growth, which was also influenced by environmental factors. In different growth periods, Qinghai spruce exhibited different water use strategies. Previous research showed that the main growth period of Qinghai spruce extended from mid-May to early August [38]. In early May, stem radial changes were due to spring rehydration following winter desiccation and subsequent precipitation [63-65]. Stem radial growth ended by late August and fluctuations in stem radial measurements were caused by tree water status [24]. Based on this, we focused on the periods from middle May to early August.

In the middle of May, low WUE was due to lack of soil water resulting in large $\Delta W$. During this dry period, the dividing cells were not elongating due to low turgor pressure resulting in low WUE. In late May and early July, high BAI and low sap flow resulted in high WUE. During these periods, precipitation increased, driving cell division and irreversible expansion of the already existing cells $[9,16,38]$, supplying tree water prompting expansion of stem radial growth, and decreasing the rate of sap flow due to reduced transpiration. A relatively long time period with large $\Delta W$ occurred before late May and early July (Figure 2); at that time, the newly-divided cells were likely not elongating due to the low cambium turgor pressure, and commenced elongation when water became available in late May and early July [24]. In the middle of July, precipitation decreased and transpiration increased, resulting in tree storage-water loss and stem radial contraction. Observations showed that a substantial stem radial contraction took place due to water loss several days after rainfall events.

During the growing season, Qinghai spruce exhibited various passive reactions to changes in environmental variables. At the beginning of the growing season, most of the water was used for stem rehydration. In the middle of the growing season, most of the water was used for transpiration under prolonged dry weather; during rainy days, water was used for cell division and irreversible expansion, and after the rain, for transpiration. Thus, precipitation played a vital role in controlling stem growth during the growing season. In the late growth stage, which included cell-wall thickening, most of the water was used for transpiration. With climate warming and increase in extreme events, changes in precipitation patterns will affect Qinghai spruce growth and transpiration.

\section{Conclusions}

Measurements of sap flow and stem radial changes in Qinghai spruce can be used to study the effects of environmental variables on tree growth. A combined use of sap flow and stem radial changes facilitates research on tree water use efficiency. In our study, the results showed that Js was nonlinearly related to $\Delta \mathrm{W}$. The effects of environmental variables on Js were greater than on $\Delta \mathrm{W}$. Qinghai spruce exhibited different water use efficiencies in different weather conditions. Water use efficiency exhibited higher values during rainy days than during day days. Precipitation, as the only source of water, was one of the most important factors promoting stem growth of Qinghai spruce in a semi-arid area of the Qilian Mountains.

Acknowledgments: This work was supported by grants from the National Natural Science Foundation of China (No. 41522102, 41601051), the National Key Research and Development Program of China (No. 2016YFC0501001), and the Funds for Creative Research Groups of China (No. 41621001).

Author Contributions: Z.H. and S.X. conceived and designed the experiments; J.D., L.C. and X.Z. performed the experiments; Q.T. and X.P. analyzed the data; P.L. and A.D. contributed analysis tools; Q.T. wrote the paper.

Conflicts of Interest: The authors declare no conflict of interest. 


\section{References}

1. Boisvenue, C.; Running, S.W. Impacts of climate change on natural forest productivity-evidence since the middle of the 20th century. Glob. Chang. Biol. 2006, 12, 862-882. [CrossRef]

2. Zeppel, M.J.B.; Wilks, J.V.; Lewis, J.D. Impacts of extreme precipitation and seasonal changes in precipitation on plants. Biogeosciences 2014, 11, 3083-3093. [CrossRef]

3. Brinkmann, N.; Eugster, W.; Zweifel, R.; Buchmann, N.; Kahmen, A. Temperate tree species show identical response in tree water deficit but different sensitivities in sap flow to summer soil drying. Tree Physiol. 2016, 36, 1508-1519. [CrossRef] [PubMed]

4. IPCC. Climate Change 2013: The Physical Science Basis; Stocker, T.F., Qin, D., Plattner, G.-K., Tignor, M., Allen, S.K., Boschung, J., Nauels, A., Xia, Y., Bex, V., Midgley, P.M., Eds.; Cambridge University Press: Cambridge, UK; New York, NY, USA, 2013; p. 1535.

5. Bennett, A.C.; McDowell, N.G.; Allen, C.D.; Anderson-Teixeira, K.J. Larger trees suffer most during drought in forests worldwide. Nat. Plants 2015, 1, 15139. [CrossRef] [PubMed]

6. Chang, X.; Zhao, W.; He, Z. Radial pattern of sap flow and response to microclimate and soil moisture in Qinghai spruce (Picea crassifolia) in the upper Heihe River Basin of arid Northwestern China. Agric. For. Meteorol. 2014, 187, 14-21. [CrossRef]

7. Liu, B.; Ming, X.; Mark, H.; Ye, Q. Observed trends of precipitation amount, frequency, and intensity in China, 1960-2000. J. Geophys. Res. 2005. [CrossRef]

8. Lin, P.; He, Z.; Du, J.; Chen, L.; Zhu, X.; Li, J. Recent changes in daily climate extremes in an arid mountain region, a case study in northwestern China's Qilian Mountains. Sci. Rep. 2017, 7, 2245. [CrossRef] [PubMed]

9. Urrutia-Jalabert, R.; Rossi, S.; Deslauriers, A.; Malhi, Y.; Lara, A. Environmental correlates of stem radius change in the endangered Fitzroya cupressoides forests of southern Chile. Agric. For. Meteorol. 2015, 200, 209-221. [CrossRef]

10. Duchesne, L.; Houle, D.; D'Orangeville, L. Influence of climate on seasonal patterns of stem increment of balsam fir in a boreal forest of Québec, Canada. Agric. For. Meteorol. 2012, 162-163, 108-114. [CrossRef]

11. Du, S.; Wang, Y.; Kume, T.; Zhang, J.; Otsuki, K.; Yamanaka, N.; Liu, G. Sapflow characteristics and climatic responses in three forest species in the semiarid Loess Plateau region of China. Agric. For. Meteorol. 2011, 151, 1-10. [CrossRef]

12. Sánchez-Costa, E.; Poyatos, R.; Sabaté, S. Contrasting growth and water use strategies in four co-occurring Mediterranean tree species revealed by concurrent measurements of sap flow and stem diameter variations. Agric. For. Meteorol. 2015, 207, 24-37. [CrossRef]

13. Steppe, K.; De Pauw, D.J.; Lemeur, R.; Vanrolleghem, P.A. A mathematical model linking tree sap flow dynamics to daily stem diameter fluctuations and radial stem growth. Tree Physiol. 2006, 26, 257-273. [CrossRef] [PubMed]

14. Beedlow, P.A.; Waschmann, R.S.; Lee, E.H.; Tingey, D.T. Seasonal patterns of bole water content in old growth Douglas-fir (Pseudotsuga menziesii (Mirb.) Franco). Agric. For. Meteorol. 2017, 242, 109-119. [CrossRef]

15. Čermák, J.; Kucera, J.; Bauerle, W.; Phillips, N.; Hinckley, T.M. Tree water storage and its diurnal dynamics related to sap flow and changes in stem volume in old-growth Douglas-fir trees. Tree Physiol. 2007, 27, 181-198. [CrossRef] [PubMed]

16. Zweifel, R.; Zimmermann, L.; Zeugin, F.; Newbery, D.M. Intra-annual radial growth and water relations of trees: Implications towards a growth mechanism. J. Exp. Bot. 2006, 57, 1445-1459. [CrossRef] [PubMed]

17. Da Silva Sallo, F.; Sanches, L.; de Morais Dias, V.R.; da Silva Palácios, R.; de Souza Nogueira, J. Stem water storage dynamics of Vochysia divergens in a seasonally flooded environment. Agric. For. Meteorol. 2017, 232, 566-575. [CrossRef]

18. Oberhuber, W.; Kofler, W.; Schuster, R.; Wieser, G. Environmental effects on stem water deficit in co-occurring conifers exposed to soil dryness. Int. J. Biometeorol. 2015, 59, 417-426. [CrossRef] [PubMed]

19. Oberhuber, W.; Hammerle, A.; Kofler, W. Tree water status and growth of saplings and mature Norway spruce (Picea abies) at a dry distribution limit. Front. Plant Sci. 2015. [CrossRef] [PubMed]

20. Jiang, Y.; Wang, B.; Dong, M.; Huang, Y.; Wang, M.; Wang, B. Response of daily stem radial growth of Platycladus orientalis to environmental factors in a semi-arid area of North China. Trees 2015, 29, 87-96. [CrossRef] 
21. Drew, D.M.; Richards, A.E.; Downes, G.M.; Cook, G.D.; Baker, P. The development of seasonal tree water deficit in Callitris intratropica. Tree Physiol. 2011, 31, 953-964. [CrossRef] [PubMed]

22. Oberhuber, W.; Gruber, A. Climatic influences on intra-annual stem radial increment of Pinus sylvestris (L.) exposed to drought. Trees 2010, 24, 887-898. [CrossRef] [PubMed]

23. Zweifel, R. Radial stem variations-A Source of tree physiological information not fully exploited yet. Plant Cell Environ. 2016, 39, 231-232. [CrossRef] [PubMed]

24. Zweifel, R.; Haeni, M.; Buchmann, N.; Eugster, W. Are trees able to grow in periods of stem shrinkage? New Phytol. 2016, 211, 839-849. [CrossRef] [PubMed]

25. Molina, A.J.; Aranda, X.; Carta, G.; Llorens, P.; Romero, R.; Savé, R.; Biel, C. Effect of irrigation on sap flux density variability and water use estimate in cherry (Prunus avium) for timber production: Azimuthal profile, radial profile and sapwood estimation. Agric. Water Manag. 2016, 164, 118-126. [CrossRef]

26. Looker, N.; Martin, J.; Jencso, K.; Hu, J. Contribution of sapwood traits to uncertainty in conifer sap flow as estimated with the heat-ratio method. Agric. For. Meteorol. 2016, 223, 60-71. [CrossRef]

27. Patankar, R.; Quinton, W.L.; Hayashi, M.; Baltzer, J.L. Sap flow responses to seasonal thaw and permafrost degradation in a subarctic boreal peatland. Trees 2014, 29, 129-142. [CrossRef]

28. Van de Wal, B.A.E.; Guyot, A.; Lovelock, C.E.; Lockington, D.A.; Steppe, K. Influence of temporospatial variation in sap flux density on estimates of whole-tree water use in Avicennia marina. Trees 2014, 29, $215-222$. [CrossRef]

29. Chang, X.; Zhao, W.; Liu, H.; Wei, X.; Liu, B.; He, Z. Qinghai spruce (Picea crassifolia) forest transpiration and canopy conductance in the upper Heihe River Basin of arid Northwestern China. Agric. For. Meteorol. 2014, 198, 209-220. [CrossRef]

30. Kume, T.; Otsuki, K.; Du, S.; Yamanaka, N.; Wang, Y.; Liu, G. Spatial variation in sap flow velocity in semiarid region trees: Its impact on stand-scale transpiration estimates. Hydrol. Process. 2012, 26, 1161-1168. [CrossRef]

31. Hernandez-Santana, V.; Fernández, J.E.; Rodriguez-Dominguez, C.M.; Romero, R.; Diaz-Espejo, A. The dynamics of radial sap flux density reflects changes in stomatal conductance in response to soil and air water deficit. Agric. For. Meteorol. 2016, 218-219, 92-101. [CrossRef]

32. Chen, D.; Wang, Y.; Liu, S.; Wei, X.; Wang, X. Response of relative sap flow to meteorological factors under different soil moisture conditions in rainfed jujube (Ziziphus jujuba Mill.) plantations in semiarid Northwest China. Agric. Water Manag. 2014, 136, 23-33. [CrossRef]

33. Kocher, P.; Horna, V.; Leuschner, C. Stem water storage in five coexisting temperate broad-leaved tree species: Significance, temporal dynamics and dependence on tree functional traits. Tree Physiol. 2013, 33, 817-832. [CrossRef] [PubMed]

34. Scholz, F.C.; Bucci, S.J.; Goldstein, G.; Meinzer, F.C.; Franco, A.C.; Miralles-Wilhelm, F. Temporal dynamics of stem expansion and contraction in savanna trees: Withdrawal and recharge of stored water. Tree Physiol. 2008, 28, 469-480. [CrossRef] [PubMed]

35. Bréda, N.; Granier, A. Intra-and interannual variations of transpiration, leaf area index and radial growth of a sessile oak stand (Quercus petraea). Ann. For. Sci. 1996, 53, 521-536. [CrossRef]

36. Knight, C.A.; Vogel, H.; Kroymann, J.; Shumate, A.; Witsenboer, H.; Mitchell-Olds, T. Expression profiling and local adaptation of Boechera holboellii populations for water use efficiency across a naturally occurring water stress gradient. Mol Ecol. 2006, 15, 1229-1237. [CrossRef] [PubMed]

37. Zhao, C.; Nan, Z.; Cheng, G.; Zhang, J.; Feng, Z. GIS-assisted modelling of the spatial distribution of Qinghai spruce (Picea crassifolia) in the Qilian Mountains, Northwestern China based on biophysical parameters. Ecol. Model. 2006, 191, 487-500. [CrossRef]

38. Tian, Q.; He, Z.; Xiao, S.; Peng, X.; Ding, A.; Lin, P. Response of stem radial growth of Qinghai spruce (Picea crassifolia) to environmental factors in the Qilian Mountains of China. Dendrochronologia 2017, 44, 76-83. [CrossRef]

39. Wang, W.; Liu, X.; An, W.; Xu, G.; Zeng, X. Increased intrinsic water-use efficiency during a period with persistent decreased tree radial growth in Northwestern China: Causes and implications. For. Ecol. Manag. 2012, 275, 14-22. [CrossRef]

40. Marshall, D.C. Measurement of sap flow in conifers by heat transport. Plant Physiol. 1958, 33, $385-396$. [CrossRef] [PubMed] 
41. Burgess, S.S.O.; Adams, M.A.; Turner, N.C.; Beverly, C.R.; Ong, C.K.; Khan, A.A.H.; Bleby, T.M. An improved heat pulse method to measure low and reverse rates of sap flow in woody plants. Tree Physiol. 2001, 21, 589-598. [CrossRef] [PubMed]

42. Barrett, D.J.; Hatton, T.J.; Ash, J.E.; Ball, M.C. Evaluation of the heat pulse velocity technique for measurement of sap flow in rainforest and eucalypt forest species of South-Eastern Australia. Plant Cell Environ. 1995, 18, 463-469. [CrossRef]

43. Zweifel, R.; Zimmermann, J.; Newbery, D.M. Modeling tree water deficit from microclimate: An approach to quantifying drought stress. Tree Physiol. 2005, 25, 147-156. [CrossRef] [PubMed]

44. Wood, S.N. Generalized Additive Models: An Introduction with R; CRC Press: Boca Raton, FL, USA, 2017.

45. Vieira, J.; Rossi, S.; Campelo, F.; Freitas, H.; Nabais, C. Seasonal and daily cycles of stem radial variation of Pinus pinaster in a drought-prone environment. Agric. For. Meteorol. 2013, 180, 173-181. [CrossRef]

46. Scholz, F.G.; Phillips, N.G.; Bucci, S.J.; Meinzer, F.C.; Goldstein, G. Hydraulic Capacitance: Biophysics and Functional Significance of Internal Water Sources in Relation to Tree Size; Springer: Rotterdam, The Netherlands, 2011; pp. 341-361.

47. Peng, X.; Fan, J.; Wang, Q.; Warrington, D. Discrepancy of sap flow in Salix matsudana grown under different soil textures in the water-wind erosion crisscross region on the Loess Plateau. Plant Soil 2014, 390, 383-399. [CrossRef]

48. Wullschleger, S.D.; Wilson, K.B.; Hanson, P.J. Environmental control of whole-plant transpiration, canopy conductance and estimates of the decoupling coefficient for large red maple trees. Agric. For. Meteorol. 2000, 104, 157-168. [CrossRef]

49. Asbjornsen, H.; Tomer, M.D.; Gomez-Cardenas, M.; Brudvig, L.A.; Greenan, C.M.; Schilling, K. Tree and stand transpiration in a Midwestern bur oak savanna after elm encroachment and restoration thinning. Agric. For. Meteorol. 2007, 247, 209-219. [CrossRef]

50. Wieser, G.; Gruber, A.; Oberhuber, W. Sap flow characteristics and whole-tree water use of Pinus cembra across the treeline ecotone of the Central Tyrolean Alps. Eur. J. For. Res. 2014, 133, 287-295. [CrossRef]

51. Wieser, G.; Grams, T.E.; Matyssek, R.; Oberhuber, W.; Gruber, A. Soil warming increased whole-tree water use of Pinus cembra at the treeline in the Central Tyrolean Alps. Tree Physiol. 2015, 35, 279-288. [CrossRef] [PubMed]

52. Pataki, D.E.; Oren, R. Species differences in stomatal control of water loss at the canopy scale in a mature bottomland deciduous forest. Adv. Water Resour. 2003, 26, 1267-1278. [CrossRef]

53. Leo, M.; Oberhuber, W.; Schuster, R.; Grams, T.E.E.; Matyssek, R.; Wieser, G. Evaluating the effect of plant water availability on inner alpine coniferous trees based on sap flow measurements. Eur. J. For. Res. 2013, 133, 691-698. [CrossRef]

54. Wieser, G.; Leo, M. Whole-tree water use by Pinus cembra at the treeline in the Central Tyrolean Alps. Plant Ecol. Divers. 2012, 5, 81-88. [CrossRef]

55. Wieser, G. Ozone. In Trace Gas Exchange in Forest Ecosystems; Springer: New York, NY, USA, 2002; pp. 211-226.

56. O'Brien, J.J.; Oberbauer, S.F.; Clark, D.B. Whole tree xylem sap flow responses to multiple environmental variables in a wet tropical forest. Plant Cell Environ. 2004, 27, 551-567. [CrossRef]

57. Liu, X.; Zhang, B.; Zhuang, J.; Han, C.; Zhai, L.; Zhao, W.; Zhang, J. The relationship between sap flow density and environmental factors in the Yangtze River delta region of China. Forests 2017, 8, 74. [CrossRef]

58. Li, W.; Si, J.; Yu, T.; Li, X. Response of Populus euphratica Oliv. sap flow to environmental variables for a desert riparian forest in the Heihe River Basin, Northwest China. J. Arid Land 2016, 8, 591-603. [CrossRef]

59. Zhao, C.Y.; Si, J.H.; Feng, Q.; Yu, T.F.; Li, P.D. Comparative study of daytime and nighttime sap flow of Populus euphratica. Plant Growth Regul. 2017, 82, 353-362. [CrossRef]

60. Si, J.; Feng, Q.; Yu, T.; Zhao, C. Nighttime sap flow and its driving forces for Populus euphratica in a desert riparian forest, Northwest China. J. Arid Land 2015, 7, 665-674. [CrossRef]

61. Devine, W.D.; Harrington, C.A. Factors affecting diurnal stem contraction in young Douglas-fir. Agric. For. Meteorol. 2011, 151, 414-419. [CrossRef]

62. King, G.; Fonti, P.; Nievergelt, D.; Büntgen, U.; Frank, D. Climatic drivers of hourly to yearly tree radius variations along a $6{ }^{\circ} \mathrm{C}$ natural warming gradient. Agric. For. Meteorol. 2012, 168, 36-46. [CrossRef]

63. Deslauriers, A.; Rossi, S.; Anfodillo, T. Dendrometer and intra-annual tree growth: What kind of information can be inferred? Dendrochronologia 2007, 25, 113-124. [CrossRef] 
64. Wang, Z.; Yang, B.; Deslauriers, A.; Qin, C.; He, M.H.; Shi, F.; Liu, J. Two phases of seasonal stem radius variations of Sabina przewalskii Kom. in northwestern China inferred from sub-diurnal shrinkage and expansion patterns. Trees 2012, 26, 1747-1757. [CrossRef]

65. Zhang, R.; Yuan, Y.; Gou, X.; Zhang, T.; Zou, C.; Ji, C.; Fan, Z.; Qin, L.; Shang, H.; Li, X. Intra-annual radial growth of Schrenk spruce (Picea schrenkiana Fisch. et Mey) and its response to climate on the northern slopes of the Tianshan Mountains. Dendrochronologia 2016, 40, 36-42. [CrossRef]

(C) 2017 by the authors. Licensee MDPI, Basel, Switzerland. This article is an open access article distributed under the terms and conditions of the Creative Commons Attribution (CC BY) license (http:/ / creativecommons.org/licenses/by/4.0/). 